FACTA UNIVERSITATIS

Series: Working and Living Environmental Protection Vol. 18, № 2, 2021, pp. 113 - 127

https://doi.org/10.22190/FUWLEP2102113T

Review Paper

\title{
TRENDS AND CHARACTERISTICS OF ROAD TRAFFIC ACCIDENTS IN OSUN STATE, SOUTH WEST NIGERIA
}

\author{
UDC 656.1.053(669)
}

\section{Nurain Bolanle Tanimowo', Dele Sunday Ogundahunsi²}

${ }^{1}$ Department of Urban and Regional Planning, Ladoke Akintola University of Technology, Ogbomoso, Nigeria

${ }^{2}$ Department of Urban and Regional Planning, Osun State University, Osogbo, Nigeria

\begin{abstract}
Road traffic accident (RTA) is a growing critical issue globally, resulting in high casualties and fatalities, especially in developing countries. This study examines the magnitude and trend of RTA and the effectiveness of road traffic safety measures in Osun State, South West Nigeria. Data on road traffic accidents from 1992 to 2016 was obtained from Nigeria's Federal Road Safety Commission (FRSC) coupled with primary data acquired from 2,209 sampled households in six hierarchically selected cities through a multi-stage stratified random procedure. The study reveals a very high positive correlation ( $r=0.97 ; p=0.001)$ between road traffic accidents and the size of the cities. Trend analysis shows a gradual decline in accident and mortality rates but increasing injury rates. The study observed a relatively higher male involvement than females in RTA at the ratio of $3: 1$ and a relatively higher occurrence among civil servants (38.2\%) and traders (27.6\%) than other occupational groups. The study concludes that the incidence of road traffic accidents varies spatially, temporally, across gender and occupational divide and that safety measures employed do not have a significant impact in preventing its occurrence in the study area. It is recommended that safety culture should be encouraged among road users apart from strengthening the institutional framework responsible for transport safety.
\end{abstract}

Key words: road traffic accident, safety, fatalities, injury, safety measures, seatbelt

Received September 10, 2021 / Accepted October 20, 2021

Corresponding author: Dele Sunday Ogundahunsi

Osun State University P.M.B 4494, Osogbo, Osun State, Nigeria

E-mail: dele.ogundahunsi@uniosun.edu.ng

(ㅇ 2021 by University of Niš, Serbia | Creative Commons Licence: CC BY-NC-ND 


\section{INTRODUCTION}

Road traffic accidents are a growing critical issue globally; an estimated 1.35 million people are killed around the world each year in road accidents, while over 50 million people sustain varying degrees of injuries from such crashes [1]. It is projected that this figure will increase by $65 \%$ over the next twenty years if no serious preventive measure is taken. The impact of road traffic accidents in many societies, and in developing countries, in particular, is likely to outstrip other threats such as communicable diseases and malnutrition [2]. Of the estimated 1.35 million people killed globally, $90 \%$ occurred in low and middle-income countries, especially Africa [3, 1]. The situation in the developing countries is critical because they are experiencing high rates of increase in vehicle ownership, population and demands for enhanced mobility and challenges in controlling other factors of road traffic accidents. Hence, more vehicles could mean more deaths unless necessary safety measures are not taken.

The 2018 WHO Global Status Report on Road Safety puts Nigeria among the nineteen countries in the world with the highest number of estimated road traffic deaths, along with China, India, the United States, Thailand, Indonesia, Brazil, Russia and others. Researches have noted the alarming situation of road traffic safety in the country, the inadequate efforts to combat it and the scanty local studies [4, 5].

The high road traffic casualty has significant impacts on the country's social, health and economic development. For instance, Premium Times [6] reported that Nigeria lost N3.2 billion to road crashes in 2017, while Yusuff [7] submitted that Nigeria loses about $30 \%$ of its Gross Domestic Product (GDP) to road traffic crashes, which is $17 \%$ of its national reserve. It also states that as of 2007, the average number of reported deaths and injuries annually from road crashes was 4,873 and 17,794, respectively, but it increased to 5,688 deaths and 27,264 injuries in 2010 .

\section{LITERATURE REVIEW}

Road safety is a challenge of epidemic proportions that has become a public health priority because of its debilitating impacts on the social and economic strata of society [8]. However, the situation is more worrisome in developing countries than in developed countries; road traffic crashes and fatalities in developed countries have slowly decreased in the past decades. Cropper and Kopts [9] observed a clear inverted U relationship between the incidence of traffic fatalities and per capita income. In their evaluation of fatality patterns among 32 high-income countries and using the International Road Traffic Accident Database (IRTAD), they discovered that between 1970 and 1999, total traffic fatalities declined by an average of $35 \%$ among the countries. In spite of the fact that vehicle kilometres travelled (VKT) increased by about $250 \%$ over the period, pedestrian fatalities per VKT declined by $80 \%$, occupants' fatalities by $76 \%$ and pedestrians and cyclists declined by $60 \%$. Worley [10] attributed the declining traffic fatalities to successful interventions such as seat belts, safety laws, enforcement of speed limits, warnings about the dangers of mixing alcohol consumption with driving, safer design and use of roads and vehicles. 
Odero [11] analysed traffic crash and injury statistics from selected African countries and reported that while road traffic crashes and injuries have slowly decreased in the past decades in developed countries, the reverse is the case with African countries. For instance, the number of reported crashes in Ghana increased by $62.8 \%$ (from 6,850 to 10,715 ), the number of reported traffic injuries increased by $48.8 \%$ (from 7,663 to 11,405 ), and the number of traffic fatalities increased by $65.3 \%$ (from 824 to 1,362) between 1994 and 1998 [12]. For Kenya, traffic crashes increased by $300 \%$ (from 3,562 to 14,342) and the number of fatalities by $43 \%$ (from 552 to 2,972) between 1965 and 1998 [13].

The same trend was observed in Nigeria, but it slowed down in the period between 1980 and 1990s due to the economic recession experienced in the country during the period. However, by the turn of the new millennium, the upward trend has accelerated again [14]. WHO [15] put Nigeria among the world's ten countries with the highest number of deaths from road traffic accidents. Odero [11], in the study of trends, risk factors and strategies for improving road traffic injuries, reported that Nigeria was second to South Africa among selected African countries by region.

Motorization rates have been on a steady increase in developing countries, and Lagarde [16] estimated that with further motorization, road traffic crashes and injuries would continue to rise to threaten the economic and human development of the continent. This ugly trend has grave implications for African countries. Apart from the financial burden, the fatalities involve the productive age group of the population; people within the 20 - 44 years age range and a three to one male-female ratio [17]. Goro [18] reported an age range of 15 - 45 years in Bauchi, Nigeria. The loss of a breadwinner or a productive family member could have a devastating impact on families and lead to impoverishment with its debilitating effects on the children and the community [19]. Given the scenario, it is obvious that there is a need to better understand the trends of road traffic accidents and the effect of safety measures in combating road traffic crashes.

\section{THE STUDY AREA}

Osun State is an inland state in south-western Nigeria, located within latitude $7^{\circ} 30^{\prime} \mathrm{N}$, longitude $4^{\circ} 30^{\prime} \mathrm{E}$ and latitude $7.5^{\circ} \mathrm{N}$ longitude $4.5^{\circ} \mathrm{E}$. The state covers a total landmass of about $9,251 \mathrm{~km}^{2}$ (3,572 square miles) and consists of thirty (30) local government areas, one (1) Area Office (Modakeke) and more than 200 towns. The 2006 national census reported a population of 3,416,959 for the state. Osun State is one of the south-western Nigerian states, a region whose transportation system is the best developed in the country. Water transportation is basically lacking, and the rail line that emanates from Lagos (Nigeria's largest city) runs through Osogbo, the state capital and some other towns. However, the most dominant form of transportation is road transportation.

Osun State is one of the ten states with alarming road safety records, being one of the states with a high incidence of road traffic crashes and casualty records in Nigeria [20]. The state is served by a fairly dense network of roads complemented by the railway line from Lagos. The state road network is about four thousand and one hundred kilometres $(4,100 \mathrm{kms})$ consisting of seven hundred and one kilometres $(701 \mathrm{kms})$ of federal (Trunk A) roads, about nine hundred kilometres $(900 \mathrm{kms})$ of state roads and about one thousand and six hundred kilometres $(1,600 \mathrm{kms})$ of local government roads [21]. However, substantial lengths of the road are in poor condition while road infrastructures are deteriorating due to 
poor construction and perennial lack of maintenance. The motorization level is one vehicle per twenty-seven persons (1 veh./27 pers.).

\section{Methodology}

Data of road traffic accidents for Osun State from 1992 to 2016 was obtained from the Federal Road Safety Commission (FRSC) of Nigeria coupled with primary data acquired from 2,209 sampled households in six hierarchically selected cities. The twenty-six (26) urban centres in the state were stratified into three different categories of large, medium and small urban centres based on the estimated population for 2016. Six of the urban centres were purposely selected corresponding to the three population categories (Figure 1). They are Osogbo and Ilesa (population > 200,000), Iwo and Ikirun (population between 100,000 and 200,000) representing medium urban centres and Ikire and Ila-Orangun (populations between 20,000 and 100,000). The six urban centres had an estimated population of one million, one hundred and four thousand, three hundred and seventy-seven (1, 104, 377). Based on the average household size of 5 [22], the total estimated household size for the selected urban centres was 220,875 and in conformity with the statistical acceptance that a randomly selected small sample from a large population will yield a true representation of the population, one percent of the households, disaggregated according to residential densities was selected for questionnaire administration.

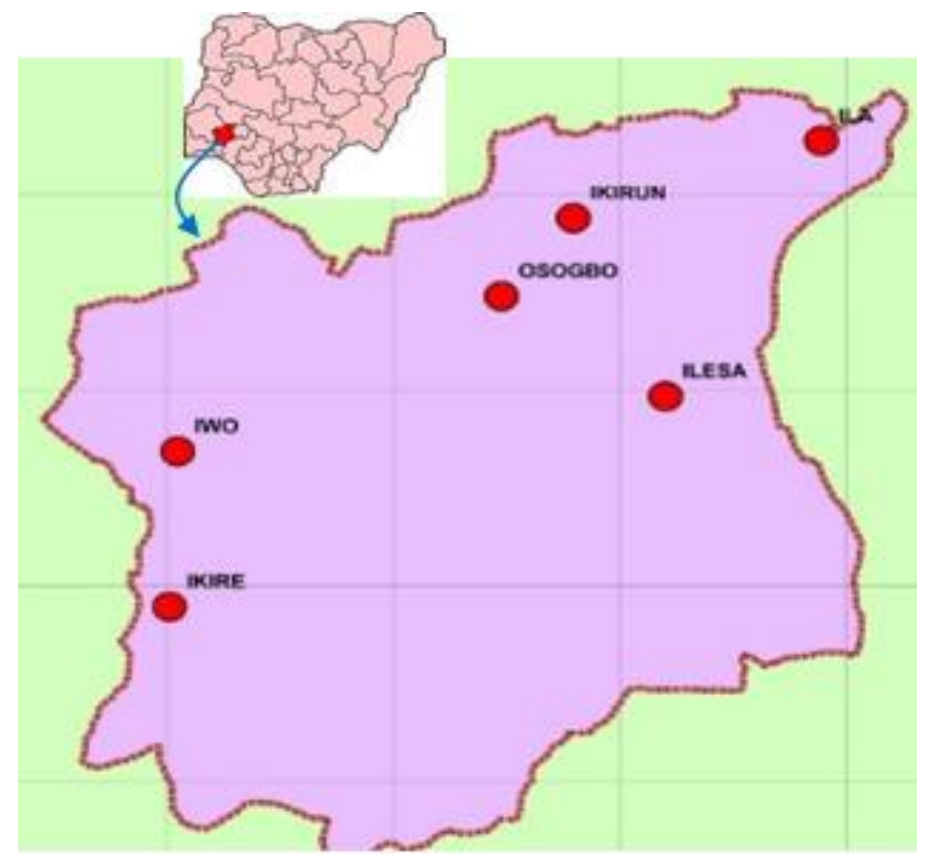

Fig. 1 Selected Cities in Osun State, Nigeria. 
In the selected cities, the residential areas were stratified into high, medium and low residential areas, and in each residential neighbourhood, systematic sampling was employed to select the required number of housing units. The household head or the most senior member of the household met during enumeration was administered the questionnaire. Due to the population density difference, a questionnaire was administered based on ratios 2, 3 and 4 corresponding to high, medium and low densities.

\section{RESULTS AND DISCUSSION}

The data analysis from the National Road Safety Commission and the primary data collected through structured questionnaires administered to sampled households are discussed below.

\subsection{Trends of road traffic accidents in Osun State $1992-2016$}

A total of 12,114 accident cases were reported between 1992 and 2016; an annual average of 484.6 accident events as evidenced in Table $1.32 .8 \%$ were classified fatal, $44.1 \%$ were serious, while the remaining $23.1 \%$ were minor. The trend of accidents as illustrated in Figure 2 shows temporal variation with three identifiable periods of high rates in 1994, 2004 and 2008. The sharp increase in 1994 could be accounted for by the fact that Osun State was created in 1991, and in a bid to develop the new state, there was a rapid increase in economic activities accompanied by a sharp increase in vehicular movements. This, coupled with a reduction in the pump price of petrol from $\$ 5$ to $\$ 3.5$ and a $45 \%$ increase in public workers' salaries, resulted in increased vehicular activities [23] and hence the increasing trend of road traffic accidents. The year 2004 witnessed three price regimes for petrol: increase from $\$ 26$ (\$.072) to $\$ 42$ (\$.12), to $\$ 50$ (\$.14) and later $\$ 65$ (\$.18) per litre. This was preceded by a $12.5 \%$ wage increase for lowestpaid workers and $4 \%$ for highest-paid workers, which obviously led to a significant increase in vehicle ownership. However, to compensate for the increased fuel price, vehicle owners switch-off vehicle engines on sloping roads to conserve fuel while public transport operators resorted to over-speeding to increase the number of daily trips and carrying overload of passengers. In addition, the year 2003 witnessed an $83 \%$ drop in budgetary allocation to road projects in the state [24]; this implies that depreciating road infrastructure was not attended to, which explains the increase in accident rate for 2004

The year 2007-2008 witnessed a decline in budgetary allocation to road projects with a direct consequence of increased accident rates. The phase between 2011 and 2014 was relatively stable with low accident rates. This was the period the state government embarked on massive road rehabilitation and construction of new roads to link various communities, thereby reducing pressure on road infrastructure and improving connectivity. It is instructive that improving road infrastructure and connectivity is one of the remedies to a road traffic accident. Trend analysis reveals a slight decrease in the incidence of accidents for the period. 
Table 1 Trends of road traffic accidents and impacts in Osun State $1992-2016$

\begin{tabular}{|c|c|c|c|c|c|c|}
\hline Year & $\begin{array}{c}\text { Reported } \\
\text { Cases }\end{array}$ & $\begin{array}{l}\text { Fatal } \\
\text { Cases } \\
\end{array}$ & $\begin{array}{c}\text { Serious } \\
\text { Cases }\end{array}$ & $\begin{array}{l}\text { Minor } \\
\text { Cases }\end{array}$ & $\begin{array}{c}\text { Persons } \\
\text { Killed }\end{array}$ & $\begin{array}{l}\text { Injured } \\
\text { Persons }\end{array}$ \\
\hline 1992 & 514 & 148 & 242 & 124 & 224 & 778 \\
\hline 1993 & 550 & 198 & 226 & 126 & 353 & 695 \\
\hline 1994 & 1071 & 318 & 463 & 290 & 432 & 1028 \\
\hline 1995 & 383 & 137 & 145 & 101 & 244 & 637 \\
\hline 1996 & 325 & 105 & 163 & 57 & 34 & 495 \\
\hline 1997 & 246 & 78 & 100 & 68 & 117 & 308 \\
\hline 1998 & 242 & 118 & 83 & 41 & 130 & 278 \\
\hline 1999 & 334 & 122 & 143 & 69 & 196 & 429 \\
\hline 2000 & 323 & 134 & 102 & 87 & 232 & 368 \\
\hline 2001 & 481 & 152 & 159 & 170 & 578 & 335 \\
\hline 2002 & 497 & 159 & 170 & 168 & 375 & 645 \\
\hline 2003 & 617 & 204 & 259 & 154 & 257 & 654 \\
\hline 2004 & 744 & 208 & 355 & 181 & 305 & 843 \\
\hline 2005 & 699 & 215 & 322 & 162 & 317 & 885 \\
\hline 2006 & 740 & 214 & 361 & 165 & 277 & 987 \\
\hline 2007 & 701 & 223 & 320 & 158 & 325 & 956 \\
\hline 2008 & 830 & 284 & 372 & 174 & 451 & 1167 \\
\hline 2009 & 745 & 187 & 374 & 184 & 261 & 967 \\
\hline 2010 & 415 & 131 & 42 & 242 & 160 & 936 \\
\hline 2011 & 270 & 86 & 171 & 13 & 155 & 1213 \\
\hline 2012 & 288 & 92 & 179 & 17 & 169 & 1259 \\
\hline 2013 & 288 & 136 & 143 & 9 & 213 & 1128 \\
\hline 2014 & 272 & 119 & 149 & 4 & 192 & 1306 \\
\hline 2015 & 274 & 108 & 158 & 8 & 137 & 1169 \\
\hline 2016 & 265 & 98 & 146 & 21 & 109 & 1019 \\
\hline Total & 12114 & 3974 & 5347 & 2793 & 6243 & 20485 \\
\hline Mean & 484.6 & 158.9 & 213.9 & 111.7 & 249.7 & 826 \\
\hline Median & 2004 & 2004 & 2005 & 2003 & 2003 & 2007 \\
\hline
\end{tabular}

Source: [25]

The three categories of accidents - fatal, serious and minor - exhibited fluctuations similar to those reported. Trend analysis reveals in Figures 2, 3 and 4 that the three have continued to decline slowly over the years.

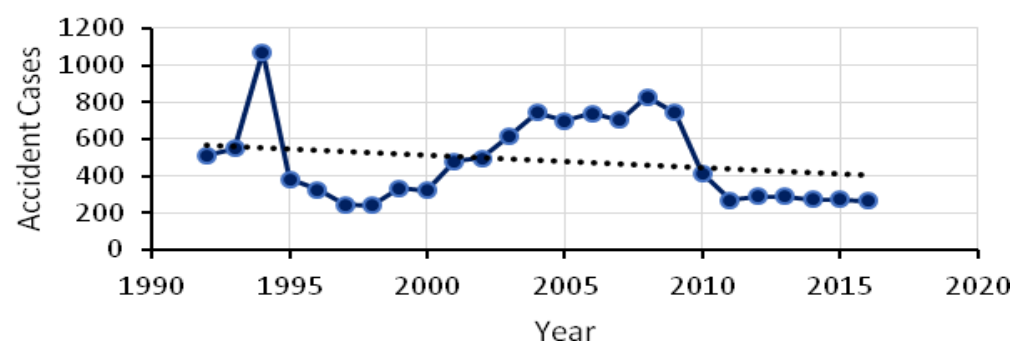

Fig. 2 Trend of accident cases in Osun State $1992-2016$. 


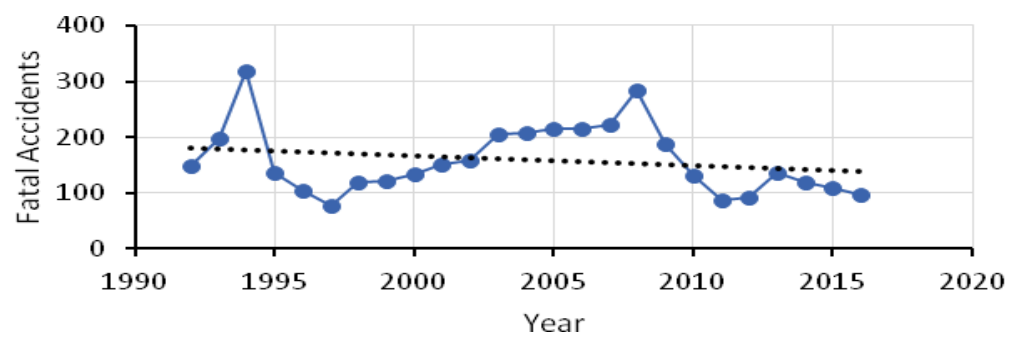

Fig. 3 Fatal accident cases $1992-2016$.

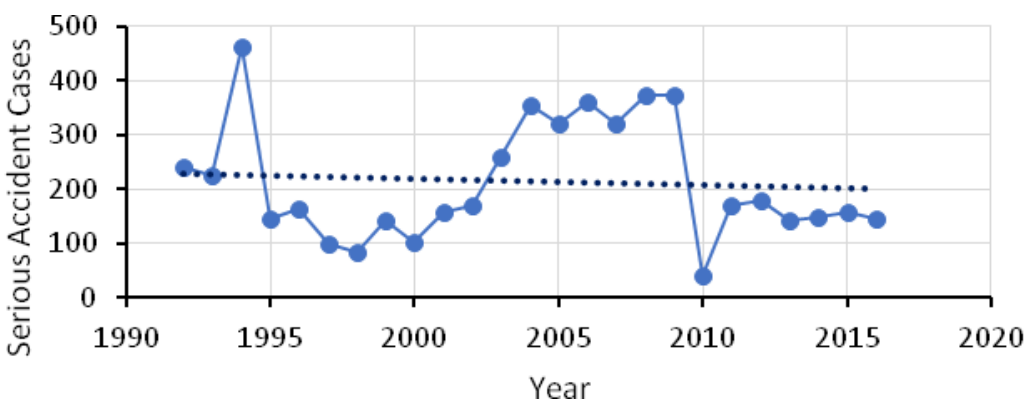

Fig. 4 Serious accident cases $1992-2016$.

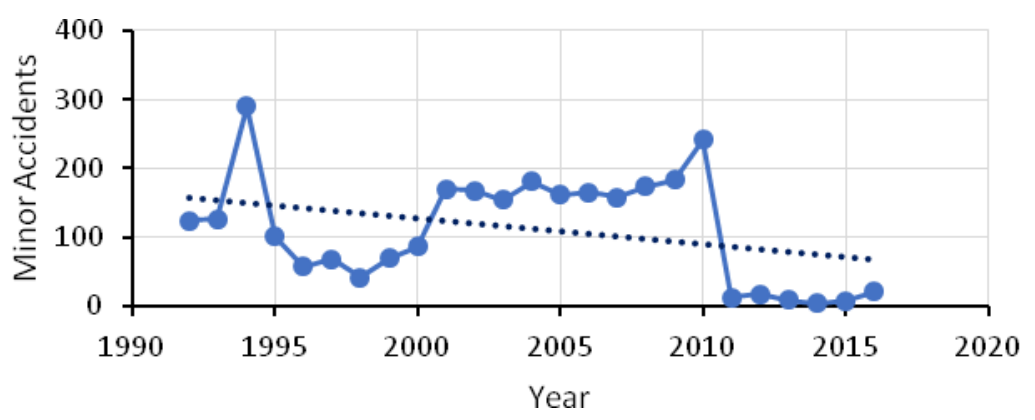

Fig. 5 Minor accident cases $1992-2016$.

\subsection{Trend of accident impacts}

The impacts were categorised into two groups - persons killed and persons injured. A total of 6,243 persons were killed between 1992 - 2016; this translates to an average annual fatality of 249.7. Fatalities recorded during the period, however, exhibited erratic behaviour as illustrated in Figure 6; from 224 in 1992, it rose to 432 persons in 1994, fell sharply to 34 in 1996 (the lowest fatality for the period under study) and then increased to 578 in 2001 (the highest fatality for the period under study). This implies a 1,700\% increase within five years. Three peak periods were identifiable; 1994, 2001 and 2008. However, a fitted trend line indicates a gentle decline in fatalities along the years.

The reported number of injured persons for the period stood at 20,485, an annual average of 826 persons. There were three significant phases observable from the trend 
curve in Figure 7; a sharp rise in 1994, a steady fall between 1995 and 2001 and a steady rise from 2002 to 2016. Trend analysis indicates a steady increase in the number of injured persons across the period under study. This is in contrast with fatalities and accident rates which were declining for the period, and it implies increased severity of accidents. Comparatively, the data shows that $23.4 \%$ of all persons actively involved in road traffic accidents for the period died while the remaining $76.6 \%$ sustained various injuries. The passively involved persons were those involved in the accident events but escaped unhurt or did not sustain any injury. These persons were not captured in the available FRSC data.

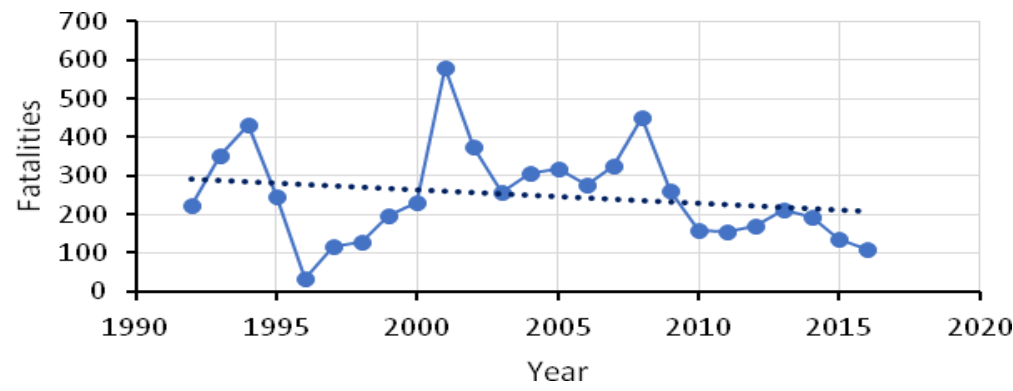

Fig. 6 Persons killed $1992-2016$.

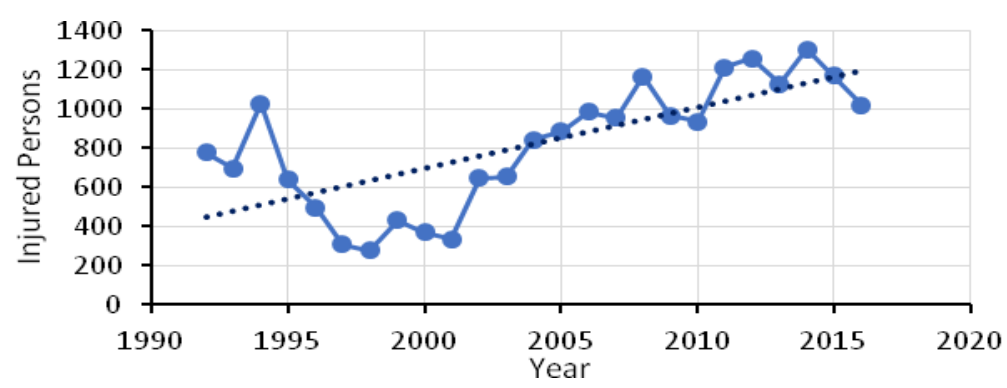

Fig. 7 Persons injured $1992-2016$

\subsection{Household reported accident events}

The data for this section was acquired by means of a structured questionnaire administered to households in the six selected cities (Osogbo, Ilesa, Iwo, Ikirun, Ila-Orangun and Ikire). The respondents reported a total of 568 accident incidents in the sampled cities. An analysis of Table 2 shows that $31 \%$ of the respondents in Osogbo were involved, $33.2 \%$ in Ilesa, $27.6 \%$ in Iwo and $21.2 \%$ in Ikirun. Ila Orangun and Ikire recorded $18.2 \%$ and $16.5 \%$ involvement, respectively. Comparatively, Osogbo had the highest accident occurrence because it is the state capital with prominent economic activities and a large number of government employees. It is a globally renowned cultural city with cultural activities that attract people from far and near. Ilesa is also a commercial city and next to Osogbo in terms of population. Commercial activities generate corresponding transportation activities with corresponding consequences. Iwo is an ancient town with many cultural activities and economic relationships with Ibadan, the capital city of neighbouring Oyo state and the third most populous city in Nigeria. 
Analysis of variance indicates significant variation in the characteristics of respondents as well as accident involvement across the six selected cities. Also, Pearson correlation analysis shows a high positive correlation between city size and road traffic accident involvement; $r=0.97$. The coefficient of determination of 0.94 indicates that $94 \%$ of the variability observed in the accident rates was due to the size of the cities.

Table 2 Cities and Accident Involvement.

\begin{tabular}{lccccccc}
\hline City & Population & Involved & $\%$ & Not Involved & $\%$ & Total & $\%$ of Total \\
\hline Osogbo & 367,635 & 213 & 31.0 & 474 & 69.0 & 687 & 33.4 \\
Ilesa & 270,195 & 156 & 33.2 & 314 & 66.8 & 470 & 17.4 \\
Iwo & 177,858 & 94 & 27.6 & 247 & 72.4 & 341 & 16.6 \\
Ikirun & 111,132 & 44 & 21.2 & 164 & 78.8 & 208 & 10.1 \\
Ila-Orangun & 87,971 & 32 & 18.2 & 144 & 81.8 & 176 & 8.6 \\
Ikire & 89,587 & 29 & 16.5 & 147 & 83.5 & 176 & 8.6 \\
\hline Total & $1,104,378$ & 568 & & 1,490 & & 2,058 & 100.0 \\
\hline
\end{tabular}

\subsection{Road traffic accident prevalence across the cities}

Road traffic accident prevalence among the sampled population (RTAP) and sampled households (HRTAP) were calculated based on Eq. (1) and (2). The results are presented in Table 3.

$$
\begin{gathered}
R T A P=\frac{\text { Accident involvement }}{\text { Population }} \times 100 \\
\text { HRTAP }=\frac{\text { Household accident involvement }}{\text { Household population }} \times 100
\end{gathered}
$$

Table 3 Road traffic accident prevalence across the cities

\begin{tabular}{lcrrrc}
\hline City & $\begin{array}{c}\text { Accident } \\
\text { Involvement }\end{array}$ & Population & Household & RTAP & HRTAP \\
\hline Osogbo & 213 & 367,635 & 73,527 & 0.058 & 0.290 \\
Ilesa & 156 & 270,195 & 54,039 & 0.058 & 0.289 \\
Iwo & 94 & 177,858 & 35,572 & 0.053 & 0.264 \\
Ikirun & 44 & 111,132 & 22,226 & 0.040 & 0.198 \\
Ila Orangun & 32 & 87,971 & 17,594 & 0.036 & 0.182 \\
Ikire & 29 & 89,587 & 17,917 & 0.032 & 0.162 \\
\hline Total & 568 & $1,104,378$ & 220,875 & 0.051 & 0.257 \\
\hline
\end{tabular}

Analysis of Table 3 reveals that Road Traffic Accident Prevalence (RTAP) and Household Road Traffic Accident Prevalence (HRTAP) is directly related to the size of the cities. The average RTAP and HRTAP for the six cities together were 0.051 persons per 100 and 0.16 households per 100 or 51 persons per 10,000 population and 16 per 10,000 households, respectively. 


\subsection{Gender involvement in accidents}

Globally, male dominance is well documented in safety literature. This study shows that $69 \%$ of the respondents involved in road traffic accidents were males, while $31 \%$ were females (Table 4). This finding agrees with Eustace and Wei [26, 27, 28, 1]. The Yoruba society where the study area is located is patrilineal with male dominance and headship in all spheres of life. The men are involved in the more adventurous and risky aspects of occupation and dominate the driving population; hence, they are more exposed to the risks of accidents.

Table 4 Gender involvement in an accident

\begin{tabular}{lccccr}
\hline City & Male & $\%$ & Female & $\%$ & Total \\
\hline Osogbo & 153 & 71.83 & 60 & 28.17 & 213 \\
Ilesa & 105 & 67.31 & 51 & 32.69 & 156 \\
Iwo & 63 & 67.02 & 31 & 32.98 & 94 \\
Ikirun & 34 & 77.27 & 10 & 22.73 & 44 \\
Ila-Orangun & 20 & 62.50 & 12 & 37.50 & 32 \\
Ikire & 17 & 58.62 & 12 & 41.38 & 29 \\
\hline Total & 392 & & 176 & & 568 \\
\hline
\end{tabular}

\subsection{Age distribution and accident involvement.}

The age distribution in Table 5 shows that $38.7 \%$ of accident victims were within the age range of $41-60$ years, $26.4 \%$ within the range of $31-40$ years and $25.9 \%$ within 18 - 30 years. In total, $91.0 \%$ of those involved in accidents belong to the active workingage group, while the remaining $9.0 \%$ consisted of the young and aged group. Montazeri [29] and Neelakantan et al., [30] reported a similar finding in their studies.

Table 5 Age distribution and accident involvement.

\begin{tabular}{lcccccc}
\hline City & $<18$ years & $18-30$ years & $31-40$ years & $41-60$ years & $>60$ years & Total \\
\hline \multirow{2}{*}{ Osogbo } & 2 & 45 & 63 & 81 & 22 & 213 \\
& $0.9 \%$ & $21.1 \%$ & $29.6 \%$ & $38.0 \%$ & $10.3 \%$ & $100.0 \%$ \\
Ilesha & 1 & 34 & 33 & 72 & 16 & 156 \\
& $0.6 \%$ & $21.8 \%$ & $21.2 \%$ & $46.2 \%$ & $10.3 \%$ & $100.0 \%$ \\
Iwo & 2 & 47 & 22 & 17 & 6 & 94 \\
& $2.1 \%$ & $50.0 \%$ & $23.4 \%$ & $18.1 \%$ & $6.4 \%$ & $100.0 \%$ \\
Ikirun & 1 & 12 & 25 & 6 & 0 & 44 \\
& $2.3 \%$ & $27.3 \%$ & $56.8 \%$ & $13.6 \%$ & $0.0 \%$ & $100.0 \%$ \\
\multirow{2}{*}{ Ila Orangun } & 0 & 1 & 5 & 25 & 1 & 32 \\
& $0.0 \%$ & $3.1 \%$ & $15.6 \%$ & $78.1 \%$ & $3.1 \%$ & $100.0 \%$ \\
Ikire & 0 & 8 & 2 & 19 & 0 & 29 \\
& $0.0 \%$ & $27.6 \%$ & $6.9 \%$ & $65.5 \%$ & $0.0 \%$ & $100.0 \%$ \\
\hline \multirow{2}{*}{ Total } & 6 & 147 & 150 & 220 & 45 & 568 \\
& $1.1 \%$ & $25.9 \%$ & $26.4 \%$ & $38.7 \%$ & $7.9 \%$ & $100.0 \%$ \\
\hline
\end{tabular}




\subsection{Educational characteristics and accident involvement}

This study discovers higher involvement of educated persons in accident events than the less educated. Table 6 shows that $65.5 \%$ of victims had more than secondary-level education. The propensity to move among educated persons is higher than those with little or no education. Across the cities studied, the same pattern was observed; higher involvement of persons with higher educational qualifications. This confirms the findings of Sami et al. [31] in FARS Province, Iran.

Table 6 Educational Characteristics and Accident Involvement

\begin{tabular}{lccccccc}
\hline \multirow{2}{*}{ City } & $\begin{array}{c}\text { No Formal } \\
\text { Educ }\end{array}$ & Pry & Sec. & $\begin{array}{c}\text { ND/ } \\
\text { NCE }\end{array}$ & $\begin{array}{c}\text { HND/ } \\
\text { BSC }\end{array}$ & $\begin{array}{c}\text { Post } \\
\text { Grad. }\end{array}$ & Total \\
\hline \multirow{2}{*}{ Osogbo } & 8 & 3 & 17 & 54 & 119 & 12 & 213 \\
\multirow{4}{*}{ Ilesa } & $3.8 \%$ & $1.4 \%$ & $8.0 \%$ & $25.4 \%$ & $55.9 \%$ & $5.6 \%$ & $100.0 \%$ \\
& 9 & 8 & 43 & 36 & 55 & 5 & 156 \\
\multirow{2}{*}{ Iwo } & $5.8 \%$ & $5.1 \%$ & $27.6 \%$ & $23.1 \%$ & $35.3 \%$ & $3.2 \%$ & $100.0 \%$ \\
& 3 & 3 & 27 & 17 & 32 & 12 & 94 \\
\multirow{2}{*}{ Ikirun } & $3.2 \%$ & $3.2 \%$ & $28.7 \%$ & $18.1 \%$ & $34.0 \%$ & $12.8 \%$ & $100.0 \%$ \\
\multirow{2}{*}{ Ila-Orangun } & 0 & 0 & 21 & 8 & 11 & 4 & 44 \\
\multirow{2}{*}{ Ikire } & $0.0 \%$ & $0.0 \%$ & $47.7 \%$ & $18.2 \%$ & $25.0 \%$ & $9.1 \%$ & $100.0 \%$ \\
& 0 & 0 & 4 & 13 & 15 & 0 & 32 \\
\multirow{2}{*}{ Total } & $0.0 \%$ & $0.0 \%$ & $12.5 \%$ & $40.6 \%$ & $46.9 \%$ & $0.0 \%$ & $100.0 \%$ \\
& 2 & 0 & 8 & 10 & 2 & 1 & 29 \\
& $27.6 \%$ & $0.0 \%$ & $27.6 \%$ & $34.5 \%$ & $6.9 \%$ & $3.4 \%$ & $100.0 \%$ \\
\hline
\end{tabular}

\subsection{Occupational characteristics and accident involvement.}

Occupational analysis of the respondents in Table 5.9 shows that regularly employed persons comprising civil servants and others employed by corporate organisations accounted for $38.2 \%$ of the victims, 27.6 were traders, while farmers and unemployed respondents accounted for $3.7 \%$ each. It should be noted that the category of civil servants in this study included those employed by corporate organizations.

In African society, the civil servants and the traders are the most mobile; the traders travel to procure and sell their products while civil servants are engaged in commuting and work-related journeys. Hence, they are more vulnerable to road traffic accidents than those engaged in other occupations. The remaining 33.8\% consisted of the students/apprentice, artisans, unemployed and farmers. Expectedly, Osogbo recorded the highest involvement among the civil servants while Ilesa recorded the highest in the category of traders. Ikirun and Ikire recorded no accidents for farmers. The least vulnerable are the farmers whose mobility understandably is mostly limited to their farms. 
Table 7 Occupational characteristics and accident involvement

\begin{tabular}{lccccccc}
\hline City & Farming & $\begin{array}{c}\text { Regular } \\
\text { Employ }\end{array}$ & Trading & Artisan & $\begin{array}{c}\text { Student/ } \\
\text { Apprentice }\end{array}$ & Unemployed & Total \\
\hline Osogbo & 7 & 102 & 49 & 25 & 21 & 9 & 213 \\
$\%$ & 3.30 & 47.90 & 23.00 & 11.8 & 9.90 & 4.20 & 100.00 \\
Ilesha & 9 & 43 & 59 & 36 & 9 & 2 & 156 \\
$\%$ & 5.80 & 27.60 & 37.80 & 23.0 & 5.80 & 1.30 & 100.00 \\
Iwo & 2 & 42 & 14 & 12 & 20 & 4 & 94 \\
$\%$ & 2.10 & 44.70 & 14.90 & 12.8 & 21.30 & 4.30 & 100.00 \\
Ikirun & 0 & 10 & 16 & 9 & 7 & 2 & 44 \\
$\%$ & 0.00 & 22.70 & 36.40 & 20.4 & 15.90 & 4.50 & 100.00 \\
Ila & 3 & 16 & 8 & 2 & 2 & 1 & 32 \\
Orangun & & & & & & & \\
$\%$ & 9.40 & 50.00 & 25.00 & 6.3 & 6.30 & 3.10 & 100.00 \\
Ikire & 0 & 4 & 13 & 7 & 2 & 3 & 29 \\
$\%$ & 0.00 & 13.80 & 44.80 & 24.1 & 6.90 & 10.30 & 100.00 \\
\hline Total & 21 & 217 & 157 & 91 & 61 & 21 & 568 \\
$\%$ & 3.70 & 38.20 & 27.60 & 16.0 & 10.70 & 3.70 & 100.00 \\
\hline
\end{tabular}

\subsection{Monthly income and accident involvement.}

Income is one of the factors that influence mobility, as higher disposable income leads to increased accessibility to transport facilities and higher demand for goods and services. An analysis of the monthly income of the respondents indicates that accident involvement varies among the income groups as well as across the cities (Table 8). $49.5 \%$ of those involved in accidents earned below $\$ 30,000$ (\$90) per month, while $26.1 \%$ earned above $\$ 50,000$ ( $\$ 140)$ per month. The former set of people patronizes public transportation and are at the mercy of the imperfections of the public transportation system. The remaining $24.5 \%$ earned between $\$ 30,001$ and N50,000 monthly. This study shows that low-income groups are more susceptible to road traffic accidents, as indicated by the United Nations Department of Economic and Social Affairs (UN DESA) [32].

Table 8 Monthly income and accident involvement.

\begin{tabular}{lcccccc}
\hline \multirow{2}{*}{ City } & below & N18,001- & N30,001- & N40,001- & Above & \multirow{2}{*}{ Total } \\
\hline \multirow{2}{*}{ Osogbo } & $\mathrm{N} 18,000$ & $\mathrm{~N} 30,000$ & $\mathrm{~N} 40,000$ & $\mathrm{~N} 50,000$ & $\mathrm{~N} 50,000$ & \\
& 25 & 60 & 20 & 18 & 90 & 213 \\
\multirow{2}{*}{ Ilesha } & $11.7 \%$ & $28.2 \%$ & $9.4 \%$ & $8.5 \%$ & $42.3 \%$ & $100.0 \%$ \\
& 43 & 52 & 26 & 16 & 19 & 156 \\
\multirow{2}{*}{ Iwo } & $27.6 \%$ & $33.3 \%$ & $16.7 \%$ & $10.3 \%$ & $12.2 \%$ & $100.0 \%$ \\
& 29 & 33 & 9 & 7 & 16 & 94 \\
\multirow{2}{*}{ Ikirun } & $30.9 \%$ & $35.1 \%$ & $9.6 \%$ & $7.4 \%$ & $17.0 \%$ & $100.0 \%$ \\
& 15 & 2 & 19 & 2 & 6 & 44 \\
\multirow{2}{*}{ Ila Orangun } & $34.1 \%$ & $4.5 \%$ & $43.2 \%$ & $4.5 \%$ & $13.6 \%$ & $100.0 \%$ \\
& 7 & 5 & 3 & 4 & 13 & 32 \\
\multirow{2}{*}{ Ikire } & $21.9 \%$ & $15.6 \%$ & $9.4 \%$ & $12.5 \%$ & $40.6 \%$ & $100.0 \%$ \\
& 6 & 4 & 13 & 2 & 4 & 29 \\
\multirow{2}{*}{ Total } & $20.7 \%$ & $13.8 \%$ & $44.8 \%$ & $6.9 \%$ & $13.8 \%$ & $100.0 \%$ \\
\hline & 125 & 156 & 90 & 49 & 148 & 568 \\
& $22.0 \%$ & $27.5 \%$ & $15.8 \%$ & $8.6 \%$ & $26.1 \%$ & $100.0 \%$ \\
\hline
\end{tabular}




\subsection{Respondents' evaluation of safety measures}

The respondents were asked to evaluate the road traffic safety measures on a 5-point ordinal Likert scale. The Likert items were assigned values ranging from 1 to 5; very effective (5), effective (4), do not know (3), ineffective (2) and very ineffective (1). The responses were collated and analysed using Eq (3)

$$
s=\frac{\sum r_{i} w_{i}}{r}
$$

Where $S$ - total score for each variable

$$
\begin{aligned}
& r_{i} \text { - number of respondents evaluating a variable } \\
& w_{i} \text { - a weight attached to each Likert item }
\end{aligned}
$$

The resulting summary shown in Table 9 indicates that drivers and vehicle licensing, enforcement of seatbelt use, and imposition of fines and penalties were effective in curbing road traffic accidents, while other measures exhibited less effective levels.

Table 9 Effectiveness of road traffic safety measures

\begin{tabular}{lcl}
\hline S/N Safety Measure & Score & Remark \\
\hline 1. Driver's licensing & 4.24 & Effective \\
2. Vehicle licensing & 4.13 & Effective \\
3. Enforcement of seatbelt use & 4.09 & Effective \\
4. Age restriction for driving & 3.39 & Less effective \\
5. Drink and drive restriction & 3.38 & Less effective \\
6. Speed limit & 3.61 & Less effective \\
7. Road signage & 3.83 & Less effective \\
8. Vehicle inspection patrol by VIO & 3.79 & Less effective \\
9. Patrol operation of FRSC & 3.96 & Less effective \\
10. Imposition of fines and penalties on offenders & 4.01 & Effective \\
11. Education and enlightenment on radio and TV & 3.92 & Less effective \\
12. Restriction on vehicle overload & 3.48 & Less effective \\
13. Age restriction on imported used vehicles & 3.13 & Less effective \\
\hline
\end{tabular}

\section{CONCLUSION AND RECOMMENDATIONS}

From the above mentioned, it can be concluded that road traffic accidents and their associated casualties vary in terms of time, space, gender, and occupation and that safety measures employed in the study area have no major impact in preventing their occurrence. The study shows that while the incidence of road traffic accidents and associated mortality has continued to decline, the number of injured persons has increased steadily.

Therefore, it is recommended that road users develop a safety culture and habits reinforced by programmes sponsored through combined public and private initiatives and that the government provide resources for more research into the mechanisms of road traffic accidents.

Adequate knowledge of the actual risks and systemic weaknesses will provide the platform for proper planning and implementation of safety initiatives towards minimizing accident occurrence [33]. Also, the institutional framework for transport safety needs to be strengthened in order to achieve the SDG target 3.6, which calls for a reduction of 
deaths and injuries due to road traffic accidents by half by 2020. Though the year 2020 has now ended, and it is evident that the goal has not yet been achieved, we firmly believe that the efforts will yield positive results towards reducing traffic deaths and injuries.

\section{REFERENCES}

1. World Health Organization (2018). Global Status Report on Road Safety 2018. [Online]. Available: http://www.who.int/violence_injury_prevention/road_traffic/en/.

2. Marquez, P. V., Farrington, J. L. (2013). The Challenge of Non-Communicable Diseases and Road Traffic Injuries in Sub-Saharan Africa. An Overview. Washington, DC. The World Bank.

3. Peden, M., Scurfield, R., Sleet, D., Mohan, D., Hyder, A.A., Jarawan, E., \& Mathers, C. (2004). World Report on Road Traffic Injury Prevention. World Health Organization (WHO), Geneva.

4. Agbonkhese, O, Yisa, G.L, Agbonkhese, E.G, Akanbi, D.O, Aka, E.O, Mondigha, E.B. (2013). Road Traffic Accidents in Nigeria: Causes and Preventive Measures. Civil and Environmental Research, 3(13), pp. 2224-5790.

5. Afolabi, J. A. \& Gbadamosi Kolawole, T. (2017). Road traffic crashes in Nigeria: Causes and consequences. Transport \& Logistics. The International Journal, 17(42), pp. 2406-1069.

6. Premium Times, (2017). Nigerians lost N3.2 billion to road crashes in 2017. [Online]. Available: https://www.premiumtimesng.com/news/top-news/227541-nigerians-lost-n3-2-billion-road-crashes2017.html.

7. Yusuff, Mulkat Ajibola, (2015). Impact Assessment of Road Traffic Accidents on Nigerian Economy. Journal of Research in Humanities and Social Science, 3(12), pp.08-16.

8. World Bank (2017). The High Toll of Traffic Injuries: Unacceptable and Preventable. World Bank, Washington, DC. (c) World Bank. Retrieved from [Online]. Available: https://openknowledge.worldbank.org/handle /10986/29129

9. Cropper M., \& Kopts E. (2012). Declining Traffic Fatalities: Lessons for Developing Countries? Resources for the future. RFF Press: An Imprint of Routledge. [Online]. Available: http://www.rff.org/Publications/WPC/Pages/09-07-27-Declining-Traffic-Fatalities.aspx

10. Worley, H. (2006). Road traffic accidents increase dramatically worldwide. Population Reference Bureau. [Online]. Available: http://www.prb.org/Publications/Articles/006/RoadTrafficAccidentsIncreaseDramaticallyWorldwide.aspx.

11. Odero W. (2004). Africa's epidemic of road traffic injuries: trends, risk factors and strategies for improvement. - Paper Presented at the Harvard Centre for Population and Development Studies on the Occasion of the World Health Day.

12. Afukaar, F. K, Antwi, P., \& Ofosu-Amaah, S. (2003). Pattern of road traffic injuries in Ghana: Implications for control. International Journal for Injury Control Safety Promotion, 10, 69-76.

13. Odero W, Khayesi M., \& Heda P. M. (2003). Road traffic injuries in Kenya: Magnitude, Causes and Status of Intervention. Injury Control Safety Promotion 10: 53-61.

14. Nantulya V. M, \& Reich M. R. (2003). Equity dimensions of road traffic injuries in low and middleincome countries. Injury Control Safety Promotion, 10(1-2):13-20.

15. World Health Organization (WHO), (2009). Global status report on road safety - time for action. WHO, Geneva.

16. Lagarde, E. (2007). Road Traffic Injury is an Escalating Burden in Africa and Deserves Proportionate Research Efforts. PLoS Medicine, Vo1. 4(6), pp. 967-71.

17. Mock C. N, Arreola-Risa C, Quansah R. (2003). Strengthening care for injured persons in less developed countries: a case study of Ghana and Mexico. Injury Control and Safety Promotion, 10: 45-51.

18. Goro E. (2005). Analysis of official statistics of road traffic violations in Bauchi road safety command between July 2000 and June 2005. Master's Thesis, Department of Sociology, Ahmadu Bello University, Zaria.

19. Mabunda M.M., Swart L.A., Seedat M. (2008). Magnitude and categories of pedestrian fatalities in South Africa. Accident Analysis \& Prevention, 40:586-593.

20. Federal Road Safety Commission, 2013 Annual Report, Nigeria.

21. Osun State Ministry of Works and Transport, (2017). Osun State Road Network, Osun State Government, Osogbo, Nigeria.

22. National Population Commission (NPC) \& ICF Macro, (2009). Nigeria Demographic and Health Survey 2008: Key Findings. Calverton, Maryland, USA. 
23. Fapohunda, T. M., Atiku, S. O. \& Lawal. O. (2012). Minimum wage implementation and management in a post-recession economy: the Nigerian experience. European Scientific Journal. 8(7), pp. 18 - 35.

24. Opawole, A., Jagboro, G. O., Babatunde, S. O. and Opawole, M. O. (2013). Critical factors in road infrastructure development in Osun State, South Western Nigeria. International Journal of Development and Sustainability, 2(1), pp. 240-253.

25. Federal Road Safety Commission (2017). Road traffic accidents in Osun State 1992 - 2016. FRSC Sector 11 Report, Nigeria.

26. Deogratias Eustace \& Heng Wei, (2010). The role of driver age and gender in motor vehicle fatal crashes, Journal of Transportation Safety \& Security,2(1), pp. 28-44. [Online]. Available: doi: 10.1080/19439961003590811

27. Sehat M., Naieni, K. H., Asadi-Lari, M., Foroushani, A. R., \& Malek-Afzali, H. (2012). Socioeconomic status and incidence of traffic accidents in metropolitan Tehran: a population-based study. International Journal of Preventive Medicine. 3(3), pp. 181-190.

28. Sadeghi-Bazargani, Homayoun et al, (2016). Epidemiological patterns of road traffic crashes during the last two decades in Iran: A review of the literature from 1996 to 2014. Archives of Trauma Research, 5(3), e32985. 2016. [Online]. Available: doi:10.5812/atr.32985.

29. Montazeri A. (2004). Road-traffic-related mortality in Iran: a descriptive study. Public Health. 118(2), pp. 110-3.

30. Neelakantan, A., Kotwal, B. A., \& Ilankumaran, M. (2017). Determinants of injuries and road traffic accidents amongst service personnel in a large defence station. Medical Journal, Armed Forces India, 73(3), pp. 216-221. [Online]. Available: doi: 10.1016/j.mjafi.2016.08.002

31. Sami, A., Moafian, G., Najafi, A., Aghabeigi, M. R., Yamini, N., Heydari, S. T., \& Lankarani K. B. (2013). Educational level and age as contributing factors to road traffic accidents. Chinese Journal of Traumatology, 16(5), pp. $281-5$.

32. United Nations Department of Economic and Social Affairs (UNEDSA), (2012). Shanghai Manual: A Guide for Sustainable Urban Development in the 21st Century. [Online]. Available: http://sustainabledevelopment.un.org/ndex.php?page=view\&type $=400 \& n r=633 \& m e n u=35$.

33. Božović, M., Ilić-Krstić, I., Mihajlović, E., Živković, S (2018). Institutional Framework for Accident Management: A Case Study in Fire Rescue Brigades Practice, Working and Living Environmental Protection 15(3), pp. 185 - 196. https://doi.org/10.22190/FUWLEP1803185B

\section{TRENDOVI I KARAKTERISTIKE SAOBRAĆAJNIH NEZGODA U DRŽAVI OSUN, JUGOZAPADNA NIGERIJA}

Saobraćajne nezgode postaju sve veći globalni problem koji rezultira velikim brojem žrtava $i$ smrtnih slučajeva, pogotovo u zemljama u razvoju. $U$ radu je dat pregled trendova $i$ obima saobraćajnih nezgoda, $i$ efikasnosti mera bezbednosti drumskog saobraćaja u državi Osun u jugozapadnoj Nigeriji. Studija obuhvata podatke Federalne komisije za bezbednost puteva u Nigeriji (FRSC) o saobraćajnim nesrećama na putevima u periodu od 1992. do 2016. kao $i$ primarne podatke na uzorku od 2.209 domaćinstava u šest hijerarhijski odabranih gradova dobijene metodom višestepenog stratifikovanog slučajnog uzorka. Došlo se do zaključka da postoji veoma visok koeficijent pozitivne korelacije $(r=0,97 ; p=0,001)$ između saobraćajnih nezgoda $i$ veličine gradova. Analiza trenda pokazuje postepeni pad stope saobraćajnih nesreća i smrtnosti s jedne strane, i povećanje stope povreda s druge strane. Takođe, primećeno je da postoji relativno veće učešće muškaraca u saobraćajnim nezgodama u odnosu na žene, čak 3:1, kao i relativno veći broj nezgoda među državnim službenicima (38,2\%) i trgovcima (27,6\%) u odnosu na druge grupe zanimanja. Došlo se do zaključka da incidenca saobraćajnih nezgoda varira prostorno, vremenski, i $u$ zavisnosti od pola i profesionalne orijentacije, kao i da primenjene mere bezbednosti nemaju značajan uticaj na prevenciju saobraćajnih nezgoda u oblasti u kojoj se sprovelo istraživanje. Data je preporuka da se među učesnicima u saobraćaju neguje bezbednosna kultura uz jačanje institucionalnog okvira za bezbednost saobraćaja.

Ključne reči: saobraćajna nezgoda, bezbednost, žrtve, mere bezbednosti, sigurnosni pojas 